\title{
ЗАЛЕЖНІСТЬ ВІДТВОРЮВАЛЬНИХ ЯКОСТЕЙ СВИНОМАТОК ВІД ТРИВАЛОСТІ ПІДСИСНОГО ПЕРІОДУ, ВАРІАНТУ ПОЄДНАННЯ ПОРІД В РІЗНІ ПОРИ РОКУ
}

\author{
Швачка Руслан Петрович \\ аспірант \\ Сумський національний аграрний університет \\ ORCID: 0000-0001-7185-4343 \\ E-mail: ruslans19hvachka@gmail.com
}

Повод Микола Григорович

доктор сільськогосподарських наук, професор

Сумський національний аграрний університет

ORCID: 0000-0001-9272-9672

E-mail: nic.pov@ukr.net.

Андрійчук Валерій Федорович

кандидат сільськогосподарських наук, доцент Поліський національний університет ORCID: 0000-0003-1143-0244

E-mail: v.f.andriuchuk@ukr.net

Вивчалась залежність відтворювальних якостей свиноматок $F_{1}$ ірландського походження за прямого та реципроктного схрещування порід велика біла і ландрас від тривалості періоду лактації впродовж чотирьох пір року в умовах степової зони України. Встановлено, що в зимову пору року не спостерігалось розбіжностей між групами свиней різних поєднань та термінів відлучення за загальною кількістю поросят, багатоплідністю, статевим співвідношенням поросят та масою їх гнізда при народженні. Водночас, за обох поєднань свиноматки зі скороченим терміном підсисного періоду мали вищу на 0,02 кә (p<0,01) великоплідність, кращу на 1,45\%...2,54\% $(p<0,01)$ збереженість поросят і як наслідок більшу на 0,17...0,29 голів їх кількість при відлученні, але нижчу інтенсивність росту - і як наслідок меншу на 25,58....27,48 ка масу гнізда та на 2,11... 2,26 ке масу однієї голови при відлученні. Навесні, свиноматки обох поєднань мали кращу на 0,28....0,56 голів потенційну та на 0,47...0,69 голів фрактичну багатоплідність, на 0,04 - 0,05 кг великоплідність, більше народжували кнуриів, мали більшу на 0,51...0,68 голови (p<0,001) кількість поросят на час відлучення за кращої на їх збереженості, але мали нижчу 1,65.. 1,69 ке (р<0,001) масу одного поросяти та на 17,25...20,72 ке масу гнізда поросят при відлученні. За інтенсивністю росту поросят до відлучення спостерігалася тенденція до їі підвищення у гніздах маток зі скороченим терміном підсисного періоду. Влітку не було виявлено суттєвих розбіжностей між свиноматками піддослідних груп за показниками загальної кількості поросят на час народження та багатоплідністю. Разом з тим, тварини 3 традиційною тривалістю підсисного періоду обох породних поєднань переважали за великоплідністю на 0,04 - 0,05 кट (р<0,001), масою гнізда під час народження на 0,37...0,47 ке, масою одного поросяти на час відлучення, та на 1,83...1,93, масою гнізда поросят на цей час 19,18...19,72 ке, середньодобовим, відносним та абсолютним приростами - при цьому спостерігалася гірша 2,84 та 3,28 \% збереженість та на 0,47- 0,59 кількість поросят на час відлучення.

Восени, тварини зі скороченим терміном підсисного періоду переважали за масою гнізда поросят при народженні на 1,81 та 2,21 ке (р<0,001), їх збереженістю на 2,11... 3,01\% (p<0,01) своїх аналогів з традиційною тривалістю підсисного періоду, тоді як останні мали перевагу на 0,08 ка за великоплідностю, на 0,26...0,39 голів за кількістю поросят при відлучені, на 2,57...2,58 кट (р<0,01) за індивідуальною масою, та на 29.38 .. 32,95 ке масою гнізда на час відлучення $(p<0,001)$, а також 2,49... 2,50 кट $(p<0,001)$ за абсолютними, на 36,94...37,86 г за середньодобовими (p<0,01) та на $18,21 \ldots 18,51 \%$ за відносними приростами. Аналізуючи зміни показників відтворювальної якості свиноматок обох генотипів встановлено, що їх багатоплідність більш залежала від пори року за скороченого терміну відлучення поросят ніж за традиційного, тоді як багатоплідність кількість поросят при відлученні мала суттєві сезонні коливання як за традиційної так і скороченій тривалості підсисного періоду у свиноматок. Пора року мала суттєвий влив на збереженість поросят у всіх піддослідних групах тварин не залежно від генотипу, або тривалості підсисного періоду. Водночас середньодобові прирости поросят помірно залежали від пори року, за обох варіантів поєднання материнської породи та тривалості підсисного періоду. Індекс комплексної оцінки відтворювальних якостей свиноматок суттєво залежав від пори року за різної тривалості підсисного періоду та менше залежав від породних поєднань свиноматок.

Ключові слова: свиноматка, поросята, підсисний період, термін відлучення поросят, багатоплідність, збереженість, поєднання породи, пора року, інтенсивність росту.

DOI: https://doi.org/10.32845/bsnau.lvst.2020.4.14

Конкурентоспроможне виробництво свинини на ринку України вимагає використання інтенсивних технологій введення свинарства, які суттєво відрізняються від тради-

ційних. При цьому раннє відлучення поросят викликають стресові стани та збільшення витрат на їх утримання [1, 4]. Дослідження термінів відлучення поросят від свиноматок в 
15, 21, 35 діб виявило, що найдоцільнішим є відлучення у 21 спостерігається багатоплідність на рівні 10,4 - 10,5 голови. Іншої думки дотримується Л.В. Польовий з співавторами [9], які стверджують, що скорочення тривалості підсисного періоду збільшує затрати корму і зменшує прибуток підприємства.

Тоді як Є. А. Козина [5] за результатами своїх досліджень стверджує, що кращим терміном відлучення поросят $€ 21$ доба, при якому свиноматки майже не втрачають своєї вгодованості, поросята раніше привчаються до поїдання комбікормів, що сприяє розвитку їх травної системи, і як наслідок спостерігається підвищення їх енергії росту. На думку $€$. В Творогової [13] застосування технології надраннього відлучення поросят дає змогу отримувати 2,5 - 2,68 опороси на рік та відлучати до 27 поросят від однієї свиноматки за цей період. При цьому, на її думку, з'являється можливість відлучати поросят з перших днів після народження доводячи їх до хорошої кондиції.

За різних термінів відлучення, важливим фактором $€$ генотип використовуваних свиней та методи їх розведення. Так у своїх дослідженнях S. Ushakova [15] дійшла висновку, що при схрещуванні помісних маток великої білої та ландрас порід 3 помісними кнурами пєтренхдюрок та дюрокхпєтрен поросята перевершують чистопородних аналогів великої білої породи за масою гнізда на час відлучення на 5,1 і 0,06 кг відповідно.

При порівнянні двопородного схрещування свиней великої білої породи з кнурами породи ландрасами голландської та ірландської селекції проведеного Ж. А Перевойко [6] кращими виявилися помісі від першого поєднання, при якому, багатоплідність свиноматок склала 10,8 голови, а кількість поросят на час відлучення - 10,2 голови, тоді як, за чистопородного розведення великої білої породи багатоплідність становила - 11,7 голови, при 10,2 голови кількості відлучених поросят. За показником збереженості гіршими на 1,6 - 7,7\% були гнізда свиней за чистопородного розведення. Для поліпшення відтворювальних якостей свиноматок А. N. Lazarevich [14] рекомендує використовувати поєднання свиней $F_{1}$ велика білахландрас 3 кнурами термінальних ліній PIC 731, маса яких при відлученні була на 22,2\% більшою у порівнянні з аналогами від схрещування порід йоркширхландрас.

Також важливим фактором який впливає на відтворювальну продуктивність свиноматок $€$ сезонність. У своїх дослідженнях М. Г. Повод та його колеги $[7,8]$ прийшли висновку, що кращу багатоплідність на 0,4 - 0,7 поросяти мають свиноматки опороси яких проходили взимку, порівняно з іншими порами року Водночас, влітку, спостерігалась найгірша збереженість поросят $73,2 \%$ i, як наслідок, най- 28 денному віці при якому, як зазначає О. М. Маменко [10]

менша їх кількість 10,8 голів в цю пору року виявилась на дату відлучення. Тоді як кращою збереженість поросят виявилась навесні $84,2 \%$ ( $<<0,01)$. На її думки Л. А. Гераніної [3] кращу багатоплідність, масу гнізда при народженні та кількість поросят при відлученні мали свиноматки в яких опороси проходили в весняний період. За повідомленнями О. О. Стародубець [12] опороси у літньо - осінні місяці дозволили отримати в середньому 10,8 голів поросят на опорос, на відміну від інших місяців де цей показник був на рівні 9,9-10,6 голів поросят.

Тому метою наших досліджень було порівняння відтворювальної продуктивності свиноматок основних материнських порід свиней - великої білої та ландрас ірландського походження за прямого та реципроктного їх схрещування, та опоросів в різні пори року в умовах промислового свинокомплексу при традиційній та скороченій тривалості підсисного періоду.

Матеріали та методи досліджень. Матеріалом для дослідження були відтворювальні якості свиноматок $\mathrm{F}_{1}$ від прямого та реципроктного схрещування тварин порід ландрас та великої білої ірландського походження, які є продуктом генетичної компанії Hermitage.

В умовах промислового репродуктора №2 ТОВ «НВП «Глобинський свинокомплекс» впродовж другого та третього тижня середнього місяця кожної пори року було сформовано за методом груп аналогів, з врахуванням віку, вгодованості та попередньої продуктивності по чотири піддослідні групи свиноматок в кількості 140 голів кожна (табл. 1). До першої та другої груп були включені тварини отримані від свиноматок ірландського ландраса та кнурів ірландської великої білої породи. До третьої та четвертої груп ввійшли свиноматки від реципроктного схрещування тварин цих порід. Свиноматки всіх чотирьох груп осіменялись штучно змішаною спермою кнурів синтетичної термінальної лінії Max Gro генетичної компанії Hermitage. Від свиноматок першої та третьої групи відлучення поросят проводилось в четвер четвертого тижня підсисного періоду, а від тварин другої та четвертої групи в четвер третього тижня підсисного періоду. В досліді за контроль були прийняті результати першої групи.

Всі свиноматки утримувалися в період поросності та лактації за ідентичних умов годівлі та мікроклімату. Опороси та вирощування підсисних поросят проводилось в секціях цеху опоросу по 60 голів в кожній, з тижневою кількістю 300 опоросів. Годівля свиноматок була повноцінною та збалансованою, комбікормами відповідних рецептур, які виготовлялись на власному комбікормовому заводі. Підгодівля поросят обох груп здійснювалась 37 доби життя престартерними кормами компанії Cargil.

Таблиця 1

Схема досліду

\begin{tabular}{|c|c|c|c|c|}
\hline \multirow{2}{*}{ Показник } & \multicolumn{4}{|c|}{ Сезон року (зима, весна, літо, осінь) } \\
\hline & I контрольна & ІІ дослідна & III дослідна & IV дослідна \\
\hline Породні поєднання свиноматок & \multicolumn{2}{|c|}{ Л $\odot \times \mathrm{BБ} \widehat{\circ}$} & \multicolumn{2}{|c|}{ ВБ $9 \times Л \sigma^{\wedge}$} \\
\hline Генотип кнурів & \multicolumn{4}{|c|}{ Max Gro } \\
\hline Тривалість підсисного періоду & 28 діб & 21 діб & 28 діб & 21 діб \\
\hline Кількість опоросів, гол. & 140 & 140 & 140 & 140 \\
\hline
\end{tabular}

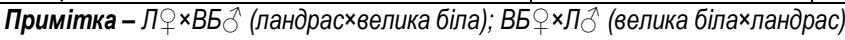

Поросята всіх піддослідних груп зважувались погніздно на час народження та при відлучені. Переміщення по-

росят між гніздами свиноматок здійснювалось в межах однієї піддослідної групи. На основ даних кількості та маси по- 
росят на час народження та відлучення досліджувалися основні показники відтворювальної здатності свиноматок за загальноприйнятими методиками. Досліджувалися наступні показники: кількість поросят на час народженні, багатоплідність, розподіл поросят у гнізді за статевою ознакою, маса гнізда на час народження, великоплідність, збереженість поросят та середньодобовий приріст.

Комплексну оцінку відтворювальних якостей досліджуваних тварин визначали використовуючи оціночний індекс за обмеженою кількістю ознак [2].

$$
\boldsymbol{I}=\boldsymbol{B}+2 \boldsymbol{W}+35 \boldsymbol{G}
$$

де: I - індекс відтворювальних якостей, балів;

В - кількість поросят при народженні, гол.;

W - кількість відлучених поросят, гол.;

G - середньодобовий приріст поросят при відлученні, кг.

Результати досліджень. За результатами досліджень які наведені в таблицях 2- 5 виявлено різні показники відтворювальної якості свиноматок за прямого та реципроктного варіанту поєднання порід матерів та термінів відлу- чення. Так, у зимовий період (табл. 2) не встановлено суттєвих розбіжностей між групами за загальною кількістю народжених поросят, багатоплідністю, співвідношенням кнурців і свинок. За масою гнізда при народженні спостерігалася тенденція до її збільшення в групах тварин з чотирьох тижневим терміном відлучення поросят. За великоплідністю свиноматки обох поєднань 3 традиційним терміном відлучення перевершували своїх ровесників з скороченим терміном відлучення на 0,02 кг $(p<0,01)$. Взимку термін відлучення поросят вплинув на їх кількість при відлученні. Так, свиноматки генотипу Л $\odot \times$ ВБ $\lesssim$ вірогідно на 0,29 голів мали більшу кількість поросят в гнізді до відлучення $(p<0,05)$, тоді як за реципроктного поєднання ця різниця склала 0,17 голів $(p<0,001)$. Більш короткий термін підсисного періоду вплинув і на збереженість поросят, яка взимку виявилася кращою на $2,54 \%(p<0,01)$ в гніздах свиноматок Л $\bigcirc \times$ ×Б $\lesssim$ і на $1,45 \% \quad(p<0,001)$ у свиноматок породного поєднання $\mathrm{BБ} \odot \times$ 几 $\mathrm{O}^{\mathrm{N}}$

\section{Відтворювальні якості свиноматок за різної тривалості підсисного періоду}

Таблиця 2 та варіанту поєднання порід взимку $\mathrm{M} \pm \mathrm{m}(\mathrm{n}=140)$

\begin{tabular}{|c|c|c|c|c|}
\hline Породні поєднання свиноматок & \multicolumn{2}{|c|}{ Л $\odot \times \mathrm{BE} \hat{\circ}$} & \multicolumn{2}{|c|}{$\mathrm{BБ} \odot \times \Omega^{\wedge}$} \\
\hline Середня тривалість підсисного періоду, діб. & 28 & 21 & 28 & 21 \\
\hline Група свиноматок & I контрольна & II дослідна & III дослідна & IV дослідна \\
\hline Всього народилося поросят, гол. & $14,82 \pm 0,143$ & $14,74 \pm 0,143$ & $14,73 \pm 0,145$ & $14,81 \pm 0,134$ \\
\hline Багатоплідність, гол. & $13,75 \pm 0,122$ & $13,73 \pm 0,133$ & $13,82 \pm 0,135$ & $13,77 \pm 0,118$ \\
\hline Кнурці, гол. & $6,96 \pm 0,067$ & $6,98 \pm 0,096$ & $6,93 \pm 0,072$ & $7,01 \pm 0,084$ \\
\hline$\%$ & 50,62 & 50,84 & 50,14 & 50,91 \\
\hline Свинки, гол. & $6,79 \pm 0,066$ & $6,75 \pm 0,053$ & $6,89 \pm 0,075$ & $6,76 \pm 0,047$ \\
\hline$\%$ & 49,38 & 49,16 & 49,86 & 49,09 \\
\hline Маса гнізда поросят при народженні, кг & $19,01 \pm 0,191$ & $18,66 \pm 0,167$ & $19,03 \pm 0,177$ & $18,74 \pm 0,154$ \\
\hline Великоплідність, кг & $1,38 \pm 0,006$ & $1,36 \pm 0,003^{* *}$ & $1,38 \pm 0,003$ & $1,36 \pm 0,003^{* *}$ \\
\hline Кількість поросят при відлученні, гол. & $12,32 \pm 0,092$ & $12,61 \pm 0,068^{*}$ & $12,52 \pm 0,100$ & $12,69 \pm 0,064^{* \star *}$ \\
\hline Збереженість, \%. & $90,31 \pm 0,589$ & $92,85 \pm 0,545^{* *}$ & $91,42 \pm 0,612$ & $92,87 \pm 0,492^{* * *}$ \\
\hline Маса одного поросяти при відлученні , кг. & $7,75 \pm 0,062$ & $5,49 \pm 0,041^{* * *}$ & $7,59 \pm 0,068$ & $5,48 \pm 0,038^{* * *}$ \\
\hline Маса гнізда поросят при відлученні, кг. & $94,52 \pm 0,563$ & $68,94 \pm 0,419^{* * *}$ & $93,93 \pm 0,592$ & $69,15 \pm 0,405^{* \star *}$ \\
\hline $\begin{array}{l}\text { Приріст живої маси поросят: } \\
\text { середньодобовий, г. }\end{array}$ & $235,98 \pm 2,329$ & $206,50 \pm 2,016^{* \star *}$ & $230,11 \pm 2,511$ & $205,68 \pm 1,876^{* *}$ \\
\hline абсолютний, кг. & $6,37 \pm 0,063$ & $4,13 \pm 0,040^{* * *}$ & $6,21 \pm 0,068$ & $4,11 \pm 0,038^{\star * *}$ \\
\hline відносний, \%. & $138,81 \pm 0,524$ & $119,92 \pm 0,495^{* * *}$ & $137,70 \pm 0,498$ & $119,79 \pm 0,459^{* \star \star}$ \\
\hline Оціночний індекс, балів. & 46,65 & 46,18 & 46,91 & 47,39 \\
\hline
\end{tabular}

Примітка - ${ }^{*}(p<0,05) ;{ }^{* *}(p<0,01) ;$

За різної тривалості підсисного періоду закономірно важчими були поросята при чотирьох тижневому підсисному періоду. У свиноматок поєднань Л $\odot$ ×ВБ дно склала 2,26 кг ( $<<0,001)$, тоді як у їх ровесниць реципроктного поєднання вона становила 2,11 кг $(p<0,001)$. Також, закономірним є більша маса гнізда на час відлучення за традиційної тривалості підсисного періоду у порівнянні з скороченим. У розрізі генетичних поєднань вона також була вищою 25,58 кг $(\mathrm{p}<0,001)$ у поєднанні свиноматок Л $\bigcirc \times$ ВБ $\lesssim$ порівняно із зворотнім варіантом, де вона становила 27,48 кг. Враховуючи більш високу енергію росту поросят в останній тиждень підсисного періоду, закономірним на наш погляд $€$ перевищення показників середньодобового приросту поросят в гніздах з традиційною тривалістю підсисного періоду. Так, за поєднань свиноматок Л $\odot$ ×ВБ чної лінії Мах Gro різниця за середньодобовими приростами вірогідно склала ( $<<0,001) 29,4$ г., тоді як за поєднання свиноматок ВБохЛठ з кнурами синтетичної лінії Max Gro така різниця склала 24,4 г. (p<0,001). Вища інтенсивність росту в підсисний період спричинила різницю в абсолютно-

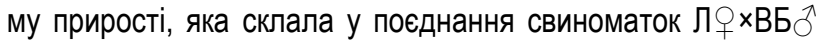
2,24 кг на користь поросят з традиційним терміном утриман-

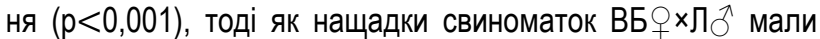
перевагу на 2,10 кг $(p<0,001)$.

Схожа картина спостерігалася і за відносними приростами, які вірогідно $(p<0,001)$ були вищими за традиційної тривалості підсисного періоду 18,9 та $17,9 \%$ у поросят нащадків свиноматок Л $\odot$ хББ ксна оцінка відтворювальних якостей свиноматок усіх чотирьох груп за допомогою оціночного індексу не виявила значної переваги певної групи. Так, в поєднання свиноматок

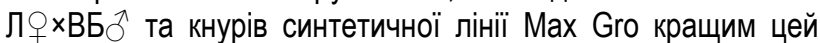
індекс був за традиційної системи відлучення, тоді як у нащадків свиноматок від реципроктного схрещування та кнурів того ж типу кращим виявився за скороченого терміну відлучення. 
Таким чином, в зимову пору року не спостерігалось розбіжностей між групами свиней різних поєднань та термінів відлучення за загальною кількістю поросят, багатоплідністю, статевим співвідношенням поросят та маси їх гнізда при народженні. Водночас, за обох поєднань свиноматки зі скороченим терміном підсисного періоду мали вищу великоплідність, кращу збереженість поросят і як наслідок більшу їх кількість на час відлучення, але нищу інтенсивність росту - і як наслідок меншу масу гнізда та однієї голови при відлученні.

У весняну пору року спостерігалась схожа тенденція (табл. 3). За загальною кількістю народжених поросят спостерігалася тенденція до її підвищення у тварин зі скороченим терміном підсисного періоду у свиноматок обох породних поєднань. Так, при поєднанні свиноматок Л $\odot$ ×ВБ $\widehat{\jmath}$ лінії Max Gro це перевершення не вірогідно склало 0,28 голови, тоді як за поєднання свиноматок реципроктного варіанту поєднання порід з тими ж кнурами перевершення склало 0,56 голів $(p<0,05)$ у тварин зі скороченим терміном підсисного періоду. Схожа тенденція спостерігалася і за багатоп-

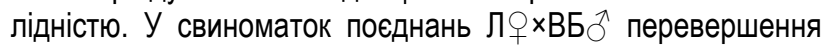
особин у яких був коротший підсисний період склало 0,47 голови р<0,01) в порівнянні 3 тваринами того ж поєднання, які мали традиційну тривалість підсисного періоду. У поєднань свиноматок ВБ $\odot \times Л \widehat{\jmath}$ аналогічне поєднання склало $0,69$ голів ( $p<0,001)$. За співвідношенням кнурців та свинок в обох поєднаннях їх вірогідно вища кількість спостерігалась в гніздах свиноматок зі скороченим терміном підсисного періоду ( $p<0,001)$. За масою гнізда поросят на час народження в поєднанні ЛфхВБð вірогідної різниці не встановлено, тоді як у гніздах свиноматок зворотного варіанту поєднання така різниця склала 0,31 кг на користь тварин зі скороченим терміном підсисного періоду. За великоплідністю тварини зі скороченим терміном підсисного періоду вірогідно поступалися 0,04 - 0,05 кг ровесницям у яких була традиційна тривалість підсисного періоду. Як і в зимовий період збереженість поросят була кращою в тварин зі скороченим терміном підсисного періоду у порівнянні з традиційним за обох породних поєднань свиноматок. Вища багатоплідність та краща збереженість поросят у підсисний період спричинила вірогідне перевершення за кількістю поросят при відлученні у свиноматок Л $\odot \times$ ВБ $\precsim$ на 0,51 голови $(p<0,001)$ та 0,68 голови $(p<0,001)$ за зворотного варіанту поєднання. Як і в попередню пору року, в гніздах свиноматок зі скороченим терміном підсисного періоду закономірно спостерігалась менша на $1,65 \ldots 1,69$ кг $(p<0,001)$ індивідуальна маса та на $17,25 \ldots 20,72$ кг маса поросят на момент відлучення ( $<<0,001)$. На відмінну від зимового періоду інтенсивність росту поросят була вищою у гніздах свиноматок зі скороченим терміном відлучення $(p<0,05)$. Це на наш погляд підтверджує гіпотезу про пік молочності свиноматок на кінець третього тижня лактації. За майже рівної інтенсивності росту, але коротшої на сім діб тривалості підсисного періоду поросята II та V дослідних груп мали вірогідно на 1,42 та 1,43 кг (p<0,001) нижчі абсолютні прирости відповідно. За результатами комплексної оцінки відтворювальних якостей вищим оціночним індексом вирізнялися свиноматки зі скороченим терміном відлучення за обох поєднань.

Таким чином, навесні, свиноматки обох поєднань мали кращу потенційну та фактичну багатоплідність, великоплідність, більше народжували кнурців, мали більшу кількість поросят при відлученні за кращої їх збереженості, але мали нищу масу одного поросяти та гнізда поросят при відлученні. За інтенсивністю росту спостерігалася тенденція до її підвищення у поросят зі скороченим терміном відлучення.

Таблиця 3

\section{Відтворювальні якості свиноматок за різної тривалості підсисного періоду}

та варіанту поєднання порід весною $\mathrm{M} \pm \mathrm{m}(\mathrm{n}=140)$

\begin{tabular}{|c|c|c|c|c|}
\hline \multirow{2}{*}{$\begin{array}{c}\text { Породні поєднання свиноматок } \\
\text { Середня тривалість підсисного періоду, діб. }\end{array}$} & \multicolumn{2}{|c|}{$\pi \bigcirc \times \mathrm{BБ}^{\top}$} & \multicolumn{2}{|c|}{$\mathrm{BБ} \odot \times \sqrt{0^{\top}}$} \\
\hline & 28 & 21 & 28 & 21 \\
\hline Група свиноматок & I контрольна & ІІ дослідна & III дослідна & IV дослідна \\
\hline Всього народилося поросят, гол. & $14,83 \pm 0,121$ & $15,11 \pm 0,120$ & $14,69 \pm 0,113$ & $15,25 \pm 0,123^{*}$ \\
\hline Багатоплідність, гол. & $13,76 \pm 0,103$ & $14,23 \pm 0,106^{* *}$ & $13,78 \pm 0,105$ & $14,47 \pm 0,107^{\star \star *}$ \\
\hline \multirow{2}{*}{ Кнурці, гол. } & $6,74 \pm 0,055$ & $7,18 \pm 0,060^{* * * *}$ & $6,77 \pm 0,054$ & $7,24 \pm 0,059^{* *+*}$ \\
\hline & 48,98 & 50,46 & 49,13 & 50,03 \\
\hline \multirow{2}{*}{$\begin{array}{r}\text { Свинки, гол. } \\
\%\end{array}$} & $7,02 \pm 0,057$ & $7,05 \pm 0,055$ & $7,01 \pm 0,059$ & $7,23 \pm 0,057^{\star *}$ \\
\hline & 51,02 & 49,54 & 50,87 & 49,97 \\
\hline Маса гнізда поросят при народженні, кг & $19,05 \pm 0,147$ & $19,15 \pm 0,141$ & $19,14 \pm 0,148$ & $19,45 \pm 0,142^{*}$ \\
\hline Великоплідність, кг & $1,39 \pm 0,003$ & $1,35 \pm 0,002^{* * *}$ & $1,39 \pm 0,001$ & $1,34 \pm 0,002^{* * *}$ \\
\hline Кількість поросят при відлученні, гол. & $12,09 \pm 0,062$ & $12,60 \pm 0,045^{* * *}$ & $12,01 \pm 0,063$ & $12,69 \pm 0,043^{* * *}$ \\
\hline Збереженість, \%. & $88,89 \pm 0,503$ & $89,56 \pm 0,486$ & $88,30 \pm 0,531$ & $88,79 \pm 0,499$ \\
\hline Маса одного поросяти при відлученні , кг. & $7,55 \pm 0,011$ & $5,90 \pm 0,028^{* * *}$ & $7,55 \pm 0,011$ & $5,86 \pm 0,027^{* * *}$ \\
\hline Маса гнізда поросят при відлученні, кг. & $91,3 \pm 0,503$ & $74,05 \pm 0,261^{* \star *}$ & $90,76 \pm 0,514$ & $74,04 \pm 0,244^{* * *}$ \\
\hline $\begin{array}{l}\text { Приріст живої маси поросят: } \\
\text { середньодобовий, г. }\end{array}$ & $221,10 \pm 2,363$ & $227,56 \pm 1,391^{*}$ & $223,55 \pm 2,498$ & $225,54 \pm 1,356$ \\
\hline абсолютний, кг. & $5,97 \pm 0,072$ & $4,55 \pm 0,028^{* * *}$ & $6,04 \pm 0,067$ & $4,51 \pm 0,027^{* * *}$ \\
\hline відносний, \%. & $125,50 \pm 4,178$ & $125,33 \pm 0,289$ & $127,33 \pm 3,842$ & $124,95 \pm 0,288$ \\
\hline Оціночний індекс, балів. & 45,68 & 47,39 & 45,62 & 47,74 \\
\hline
\end{tabular}

Примітка - * $(p<0,05) ;{ }^{* *}(p<0,01) ;{ }^{* * *}(p<0,001) ;$

У літню пору року (табл. 4) не встановлено достовірної різниці за показниками кількості поросят на час народження та багатоплідністю між досліджуваними групами тварин. Співвідношення статей між кнурцями і свинками не містило достовірної різниці, як в розрізі генетичних поєднань так і віку відлучення поросят. За масою гнізда на час народження поросята 3 традиційною тривалістю підсисного періоду перевершували своїх ровесників зі скороченою його 
тривалістю на 0,37...0,47 кг за обох породних поєднань. Свиноматки обох породних поєднань мали на 0,04...0,05 кг ( $<<0,001)$ гіршу великоплідність за скороченого терміну підсисного періоду у порівнянні з тваринами з традиційним підсисним періодом. Вища кількість поросят на час відлучення спостерігалася у тварин породного поєднання

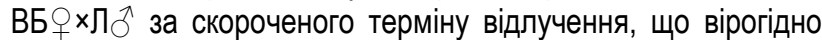
перевершувало на 0,47...0,59 голів ( $<<0,001)$ тварин з I та III груп, у яких був традиційним термін підсисного періоду. Вищою, в цю пору рок, виявилась на 19,18 та 19,72кг ( $<<0,001)$ і маса гнізда поросят при відлучені відповідно. Як і в попередні пори року більш тривале знаходження поросят біля свиноматок впливає на їх збереженість. Так, тварини

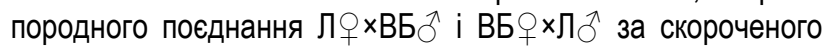
терміну відлучення мали вірогідно кращу $(p<0,001)$ збереженість поросят на 2,84 та 3,28 \% відповідно. Тварини генотипу Л $\triangle$ ВББ $\curvearrowright$ мали вірогідно вищу різницю на 1,93 кг за індивідуальною масою поросят на час відлучення $(p<0,001)$, тоді як для їх аналогів ВБ $9 \times Л{ }^{\wedge}$ вона становила 1,83 кг
( $р<0,001)$. Внаслідок вищої середньої маси поросят на час відлучення у тварин 3 традиційною тривалістю підсисного періоду спостерігалися у них і вищий середньодобовий їх приріст поросят. Так свиноматки породного поєднання

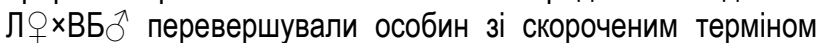
підсисного періоду на 13,61 г (p<0,001) у порівнянні $з$ їх аналогом за традиційного. У свиноматок ВБ $\odot \times$ Л ${ }^{\lambda}$ аналогічне перевищення становило 10,17 г ( $<<0,001)$.

Різниця за абсолютним приростами між тваринами

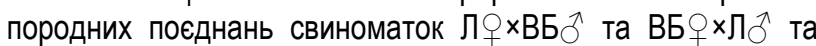
кнурів синтетичної лінії Мax Groза різних термінів відлучення вірогідно склала 1,87 кг ( $<<0,001)$, та 1,79 кг ( $<<0,001)$ відповідно. Дана тенденція збереглася і за відносними приростами, які були вірогідно вищими у тварин з традиційною тривалістю підсисного періоду 14,37...14,66 \% (p<0,001) за обох породних поєднань. За комплексною оцінкою відтворювальних якостей кращими виявились свиноматки породного поєднання ЛохВБ今ે 3 традиційною тривалістю підсисного періоду.

Таблиця 4

\section{Відтворювальні якості свиноматок за різної тривалості підсисного періоду}

та варіанту поєднання порід влітку $M \pm m(n=140)$

\begin{tabular}{|c|c|c|c|c|}
\hline Породні поєднання свиноматок & \multicolumn{2}{|c|}{ Л + × ВБ ${ }^{\lambda}$} & \multicolumn{2}{|c|}{ ВБО $\times Л \hat{0}$} \\
\hline Середня тривалість підсисного періоду, діб. & 28 & 21 & 28 & 21 \\
\hline Група свиноматок & I контрольна & ІІ дослідна & III дослідна & IV дослідна \\
\hline Всього народилося поросят, гол. & $14,87 \pm 0,117$ & $14,83 \pm 0,106$ & $14,93 \pm 0,129$ & $14,81 \pm 0,104$ \\
\hline Багатоплідність, гол. & $13,83 \pm 0,102$ & $14,02 \pm 0,099$ & $14,06 \pm 0,113$ & $14,05 \pm 0,094$ \\
\hline \multirow{2}{*}{ Кнурці, гол. } & $6,82 \pm 0,054$ & $7,03 \pm 0,056^{* *}$ & $6,91 \pm 0,060$ & $7,03 \pm 0,054^{* *}$ \\
\hline & 49,31 & 50,14 & 49,15 & 50,04 \\
\hline \multirow{2}{*}{$\begin{array}{r}\text { Свинки, гол. } \\
\% \\
\end{array}$} & $7,01 \pm 0,059$ & $6,99 \pm 0,053$ & $7,15 \pm 0,062$ & $7,02 \pm 0,049$ \\
\hline & 50,69 & 49,86 & 50,85 & 49,96 \\
\hline Маса гнізда поросят при народженні, кг & $19,41 \pm 0,150$ & $18,94 \pm 0,141^{*}$ & $19,62 \pm 0,174$ & $19,04 \pm 0,132$ \\
\hline Великоплідність, кг & $1,40 \pm 0,003$ & $1,35 \pm 0,003^{* * *}$ & $1,40 \pm 0,005$ & $1,36 \pm 0,002^{* * *}$ \\
\hline Кількість поросят при відлученні, гол. & $11,96 \pm 0,060$ & $12,52 \pm 0,052^{* \star *}$ & $12,08 \pm 0,059$ & $12,55 \pm 0,047^{\star \star \star}$ \\
\hline Збереженість, \%. & $87,43 \pm 0,512$ & $90,27 \pm 0,484^{* \star *}$ & $87,04 \pm 0,536$ & $90,32 \pm 0,439^{* \star *}$ \\
\hline Маса одного поросяти при відлученні , кг. & $7,60 \pm 0,044$ & $5,67 \pm 0,032^{* * \star}$ & $7,51 \pm 0,045$ & $5,68 \pm 0,029^{* * \star}$ \\
\hline Маса гнізда поросят при відлученні, кг. & $90,25 \pm 0,407$ & $70,53 \pm 0,280^{* * *}$ & $90,17 \pm 0,430$ & $70,92 \pm 0,241^{* * *}$ \\
\hline $\begin{array}{l}\text { Приріст живої маси поросят: } \\
\text { середньодобовий, г. }\end{array}$ & $229,39 \pm 1,646$ & $215,78 \pm 1,614^{* \star *}$ & $226,50 \pm 1,678$ & $216,33 \pm 1,454^{\star \star *}$ \\
\hline абсолютний, кг. & $6,19 \pm 0,044$ & $4,32 \pm 0,032^{* \star *}$ & $6,12 \pm 0,045$ & $4,33 \pm 0,029^{* * *}$ \\
\hline відносний, \%. & $137,10 \pm 0,357$ & $122,44 \pm 0,404^{* \star *}$ & $136,80 \pm 0,404$ & $122,43 \pm 0,360^{\star \star \star}$ \\
\hline Оціночний індекс, балів. & 48,78 & 46,61 & 46,15 & 46,72 \\
\hline
\end{tabular}

Примітка - ${ }^{*}(p<0,05) ;{ }^{* *}(p<0,01) ;$

Отож, у літню пору року не було виявлено суттєвих розбіжностей між свиноматками дослідних груп за показниками загальної кількості поросят на час народження та багатоплідністю. Разом з тим, тварини з традиційною тривалістю підсисного періоду обох породних поєднань переважали за великоплідністю, масою гнізда на час народження, масою одного поросяти на час відлучення, масою гнізда поросят на час відлучення, середньодобовим, відносним та абсолютним приростами - при цьому спостерігалася гірша збереженість та кількість поросят на час відлучення.

Восени загальна кількість поросят на час народження була вірогідно вищою на 0,64 та 0,86 голови ( $p<0,001)$ у тварин породних обох генотипових поєднань за традиційної тривалості підсисного періоду у порівнянні зі скороченим (табл. 5). Спостерігається добре виражена перевага тварин за багатоплідністю при традиційному терміні відлучення.

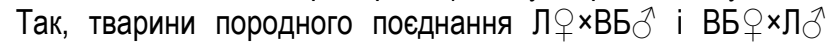
перевершували свиноматок з тим же варіантом породного поєднання при скороченому терміні підсисного періоду на $0,57 \ldots 0,80$ голови $(p<0,001)$ відповідно. В осінню пору, співвідношення кнурців і свинок за традиційної тривалості підсисного періоду в обох поєднаннях було вірогідно вищим $(p<0,001)$ ніж за скороченого. Маса гнізда поросят на час народження виявилася вірогідно вищою на 1,81 та 2,21 кг $(p<0,001)$ за традиційного терміну відлучення як у тварин

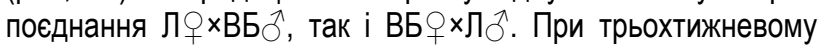
терміні підсисного періоду свиноматки без залежності від варіанта поєднання породи мали вірогідно меншу $(p<0,001)$ індивідуальну масу поросят при народженні на 0,08 кг. Як і в літній період збереженість поросят була кращою у тварин зі скороченим терміном підсисного періоду. Так, свиноматки породного поєднання ЛохВБ今 мали на 2,11 \% вірогідно вищі $(p<0,01)$ показники збереженості, тоді як при зворотному поєднання ця різниця становила $3,01 \%(p<0,01)$. Більшу кількість поросят відлучали у свиноматок з традиційною тривалістю підсисного періоду. Тварини о обох породних 
поєднань за цим показником вірогідно перевершували $(p<0,01)$ своїх аналогів на $0,26 \ldots 0,39$ голови зі скороченим терміном відлучення. Як і в минулі сезони року поросята, що утримувалися біля свиноматок протягом трьох тижнів мають вірогідно нижчі 2,57...2,58 кг (р<0,01) показники індивідуальної маси на час відлучення та на 29.38...32,95 кг маси гнізда на момент відлучення.

Відтворювальні якості свиноматок за різної тривалості підсисного періоду та варіанту поєднання порід восени $\mathrm{M} \pm \mathrm{m}(\mathrm{n}=140)$

\begin{tabular}{|c|c|c|c|c|}
\hline Породні поєднання свиноматок & \multicolumn{2}{|c|}{ Л $x_{\mathrm{B}} \mathrm{O}^{\lambda}$} & \multicolumn{2}{|c|}{$\mathrm{BБ} \odot \times Л \boldsymbol{O}^{\lambda}$} \\
\hline Середня тривалість підсисного періоду, діб. & 28 & 21 & 28 & 21 \\
\hline Група свиноматок & I контрольна & II дослідна & III дослідна & IV дослідна \\
\hline Всього народилося поросят, гол. & $14,75 \pm 0,122$ & $14,11 \pm 0,135^{* \star *}$ & $14,87 \pm 0,113$ & $14,01 \pm 0,135^{* \star *}$ \\
\hline Багатоплідність, гол. & $13,71 \pm 0,102$ & $13,14 \pm 0,064^{* \star *}$ & $13,94 \pm 0,101$ & $13,14 \pm 0,121^{\star \star \star}$ \\
\hline Кнурці, гол. & $6,82 \pm 0,056$ & $6,56 \pm 0,069^{* *}$ & $6,95 \pm 0,054$ & $6,58 \pm 0,030^{* * \star}$ \\
\hline$\%$ & 49,74 & 49,92 & 49,86 & 50,08 \\
\hline Свинки, гол. & $6,89 \pm 0,056$ & $6,58 \pm 0,064^{* * *}$ & $6,99 \pm 0,055$ & $6,56 \pm 0,062^{* * *}$ \\
\hline$\%$ & 50,24 & 50,08 & 50,14 & 49,92 \\
\hline Маса гнізда поросят при народженні, кг & $19,04 \pm 0,152$ & $17,23 \pm 0,164^{* * *}$ & $19,43 \pm 0,141$ & $17,22 \pm 0,157^{\star \star *}$ \\
\hline Великоплідність, кг & $1,39 \pm 0,004$ & $1,31 \pm 0,002^{* \star *}$ & $1,39 \pm 0,001$ & $1,31 \pm 0,002^{* \star \star}$ \\
\hline Кількість поросят при відлученні, гол. & $12,14 \pm 0,060$ & $11,88 \pm 0,074^{* *}$ & $12,20 \pm 0,059$ & $11,86 \pm 0,073^{* *}$ \\
\hline Збереженість, \%. & $89,50 \pm 0,476$ & $91,61 \pm 0,395^{* * *}$ & $88,38 \pm 0,472$ & $91,39 \pm 0,389^{* *}$ \\
\hline Маса одного поросяти при відлученні , кг. & $8,13 \pm 0,043$ & $5,55 \pm 0,037^{\star \star \star}$ & $8,12 \pm 0,041$ & $5,56 \pm 0,036^{\star \star \star}$ \\
\hline Маса гнізда поросят при відлученні, кг. & $98,04 \pm 0,396$ & $65,09 \pm 0,259^{* * *}$ & $98,44 \pm 0,383$ & $65,06 \pm 0,247^{* \star \star *}$ \\
\hline $\begin{array}{l}\text { Приріст живої маси поросят: } \\
\text { середньодобовий, г. }\end{array}$ & $249,63 \pm 1,588$ & $211,77 \pm 1,836^{* * *}$ & $249,18 \pm 1,502$ & $212,24 \pm 1,812^{* * *}$ \\
\hline абсолютний, кг. & $6,74 \pm 0,043$ & $4,24 \pm 0,037^{* * *}$ & $6,73 \pm 0,041$ & $4,24 \pm 0,036^{* * *}$ \\
\hline відносний, \%. & $141,23 \pm 0,325$ & $122,69 \pm 0,431^{* * *}$ & $141,03 \pm 0,265$ & $122,82 \pm 0,422^{* \star *}$ \\
\hline Оціночний індекс, балів. & 46,72 & 44,31 & 46,06 & 44,29 \\
\hline
\end{tabular}

Примітка - * $(p<0,05) ;{ }^{* *}(p<0,01) ;$

Різниця тривалості підсисного періоду вплинула на показники середньодобового, абсолютного та відносного приростів. Так, поросята породних поєднання як, Л×ВБО так ВБ $9 \times$ Л 3 кнурами синтетичної лінії Max Gro за традиційного терміну відлучення вірогідно перевершували $(p<0,01)$ своїх аналогів при трьох тижневому підсисному періоді за середньодобовими приростами на $36,94 \ldots 37,86$ г. Восени, абсолютний приріст виявився кращим на 2,5 кг $(\mathrm{p}<0,001)$ у поросят в гніздах свиноматок Л $\times$ ×ВБ ${ }^{\lambda}$ і на 2,49 кг $(p<0,001)$ у нащадків маток ВБ $\propto \times Л \widehat{\jmath}$ за традиційного терміну відлучення в порівнянні зі скороченим. За комплексною оцінкою відтворювальних якостей восени встановлено перевагу за цим показником у свиноматок з традиційною тривалістю підсисного періоду. Найвищим цей показник мали тварини контрольної групи 46,72 бала, що на $1,41 \ldots 5,20$ \% більше у порівнянні 3 свиноматками інших груп.

Таким чином, восени, тварини зі скороченим терміном підсисного періоду переважали за масою гнізда при народженні, кількістю відлучених поросят та їх збереженістю, аналогів з традиційною тривалістю підсисного періоду, тоді як останні мали перевагу за великоплідностю, індивідуальною масою та масою гнізда на час відлучення, а також абсолютними середньодобовими та відносними приростами.

В результаті аналізу сезонної динаміки встановлено, що пора року суттєво впливала на відтворювальні якості свиноматок обох генетичних поєднань, як за традиційного, так і скороченого терміну відлучення. Так, багатоплідність свиноматок (рис. 1) зростала навесні та знижувалася восени. У свиноматок поєднання Л ну відлучення багатоплідність виявилася досить стабільною від 13,71 до 13,83 поросят на опорос, тоді як за скороченого терміну відлучення вона була більш варіабельною - і змінювалася від 13,14 голів восени до 14,23 навесні, взимку та влітку цей показник мав проміжні значення. За породного поєднання свиноматок ВБㅇㅈㅅㅊ багатоплідність також була менш мінливою за традиційного способу відлучення поросят 13,78-14,06 голови. Тоді, як за скороченого терміну відлучення вона варіювала від 13 - 14 голів восени до 14,47 восени. Взимку та влітку вона становила $13,77,14,05$ голови відповідно.

Таким чином, в обох генотипів свиноматок багатоплідність більш залежала від пори року за скороченого терміну відлучення поросят ніж за традиційного. 


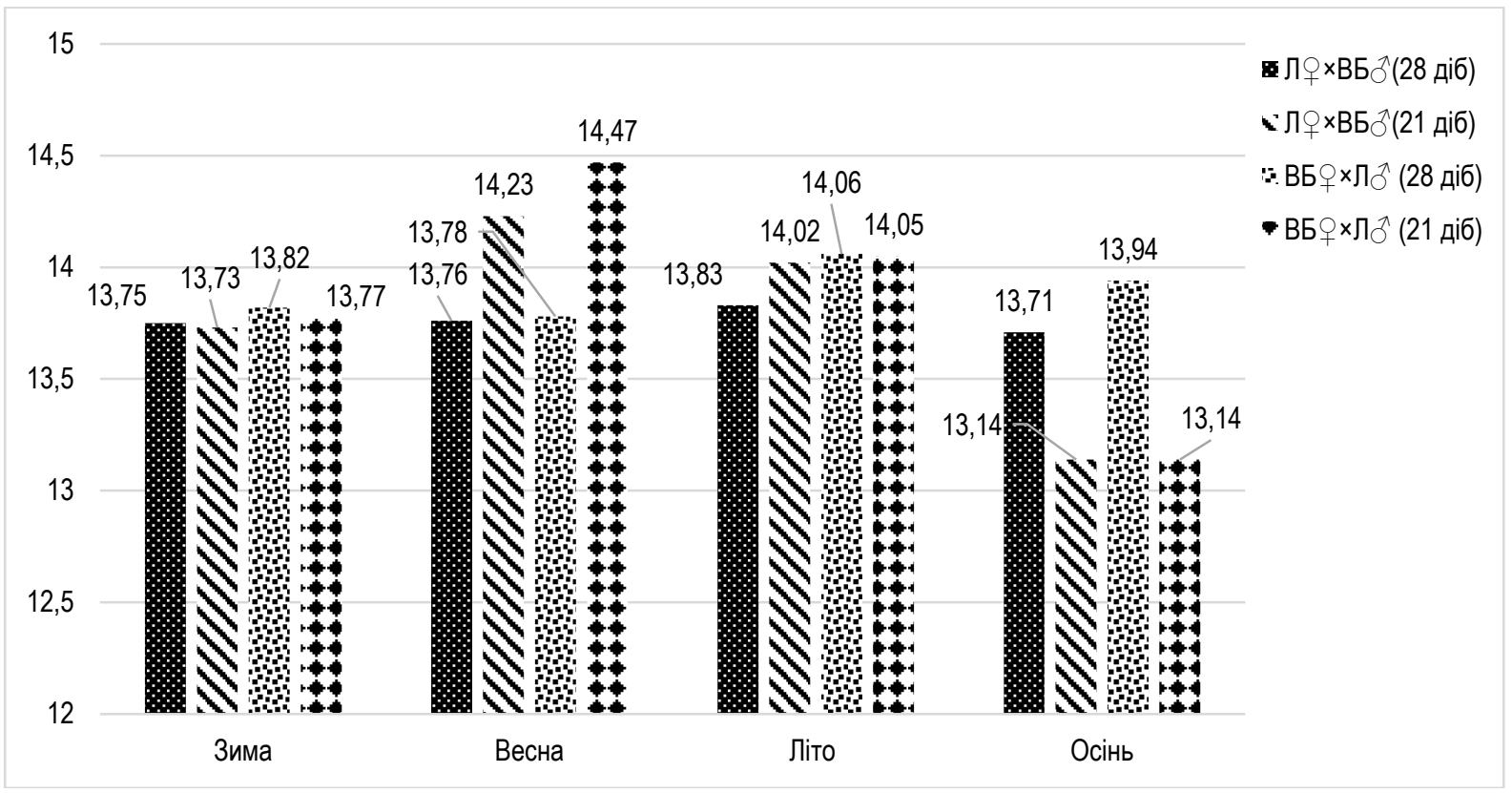

Рис. 1. Динаміка зміни показника багатоплідності протягом року, голів

За кількістю поросят при відлученні (рис. 2) простежувалася більш вагомі сезонні коливання. Так, у свиноматок

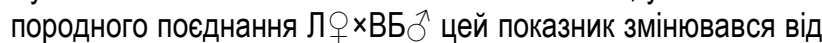
12,32 голови взимку до 11,96 голови влітку. Тоді як, за скороченого терміну він був майже рівним взимку, навесні та влітку - 12,69...12,52. Восени він зменшувався на 0,64...0,73 голови. У маток поєднання ВБ $\bigcirc$ ×Л спостерігались більш суттєві коливання як за традиційного так і скороченого терміну відлучення. За традиційного терміну вони варіювалися від 12,01 на весні до 12,52 взимку. Тоді як, за скороченого терміну найвищий показник був взимку та навесні 12,69 голів, та зменшився на 0,14 голови в літню пору року і на 0,83 голови восени.

Таким чином, як і багатоплідність кількість поросят при відлученні мала суттєві сезонні коливання як за традиційної так і скороченій тривалості підсисного періоду у свиноматок.

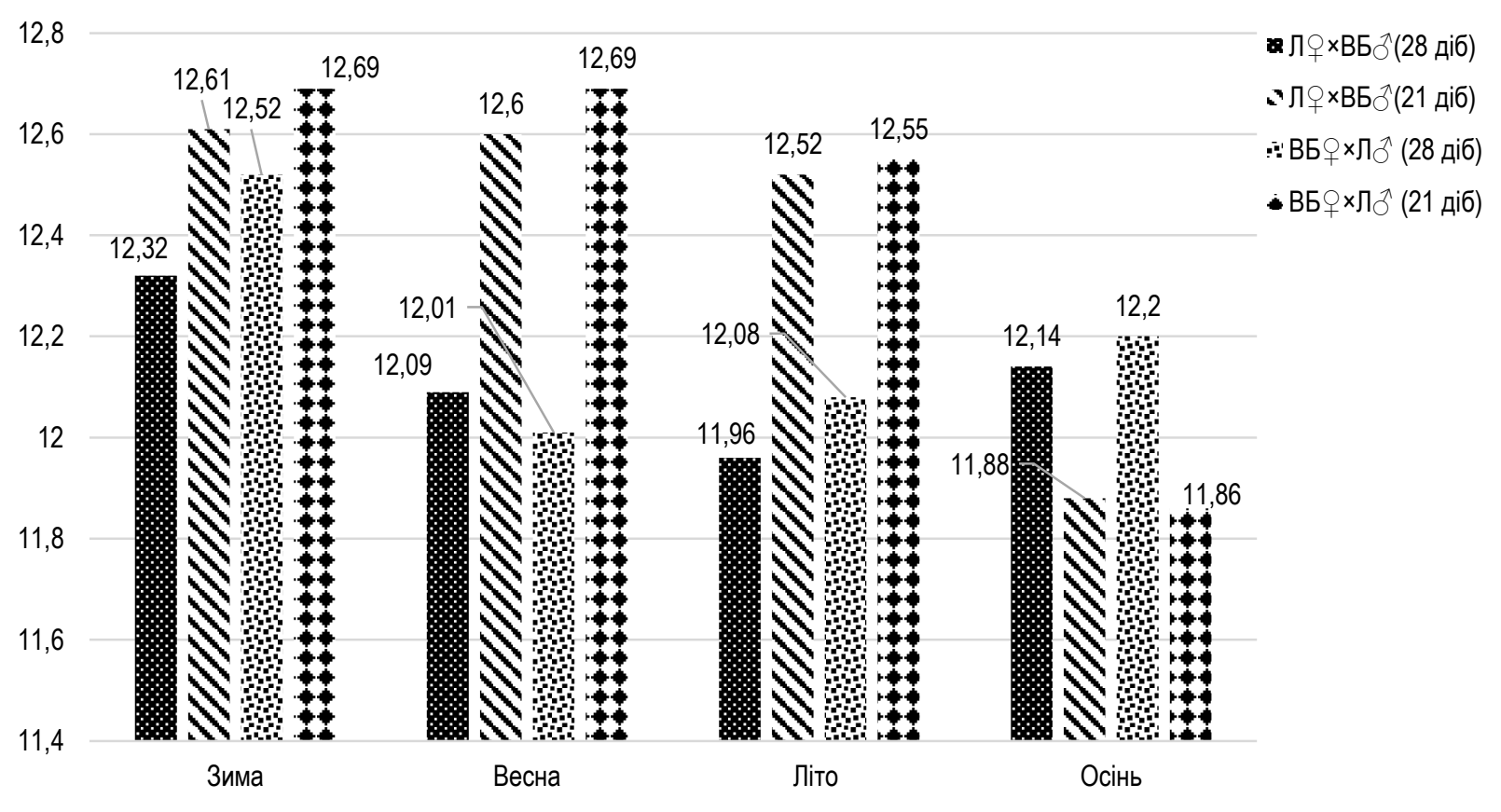

Рис.2 Динаміка зміни показника кількості поросят на час відлучення протягом року, голів

Збереженість поросят суттєво залежить від пори року як за традиційної так і за скороченої тривалості підсисного періоду в обох породних поєднань свиноматок. Отож, збереженість поросят (рис. 3) виявилась найкращою взимку за обох поєднань порід матерів та термінів відлучення поросят. Вона спадала навесні та влітку збільшувалась 3 настан- ням осінної пори року. У свиноматок поєднання ЛфхВБ乞 за традиційного та скороченого терміну відлучення збереженість виявилася варіабельною 87,43...90,31\%, і 89,56...92,85\% відповідно. При поєднанні порід ВБохлภ мінливість також була порівняно високою. Так за традиційної тривалості підсисного періоду коливання склали

Вісник Сумського національного аграрного університету 
87,04...91,42 \%. Тоді як за скороченого терміну відлучення збереженість змінювалася від 92,87 \% взимку до 88,79\% навесні і збільшилася влітку до 90,32 \%, та відновилася на $91,39 \%$ восени.
Отже, сезон року мав суттєвий влив на збереженість поросят у всіх піддослідних групах тварин не залежно від генотипу, або тривалості підсисного періоду.

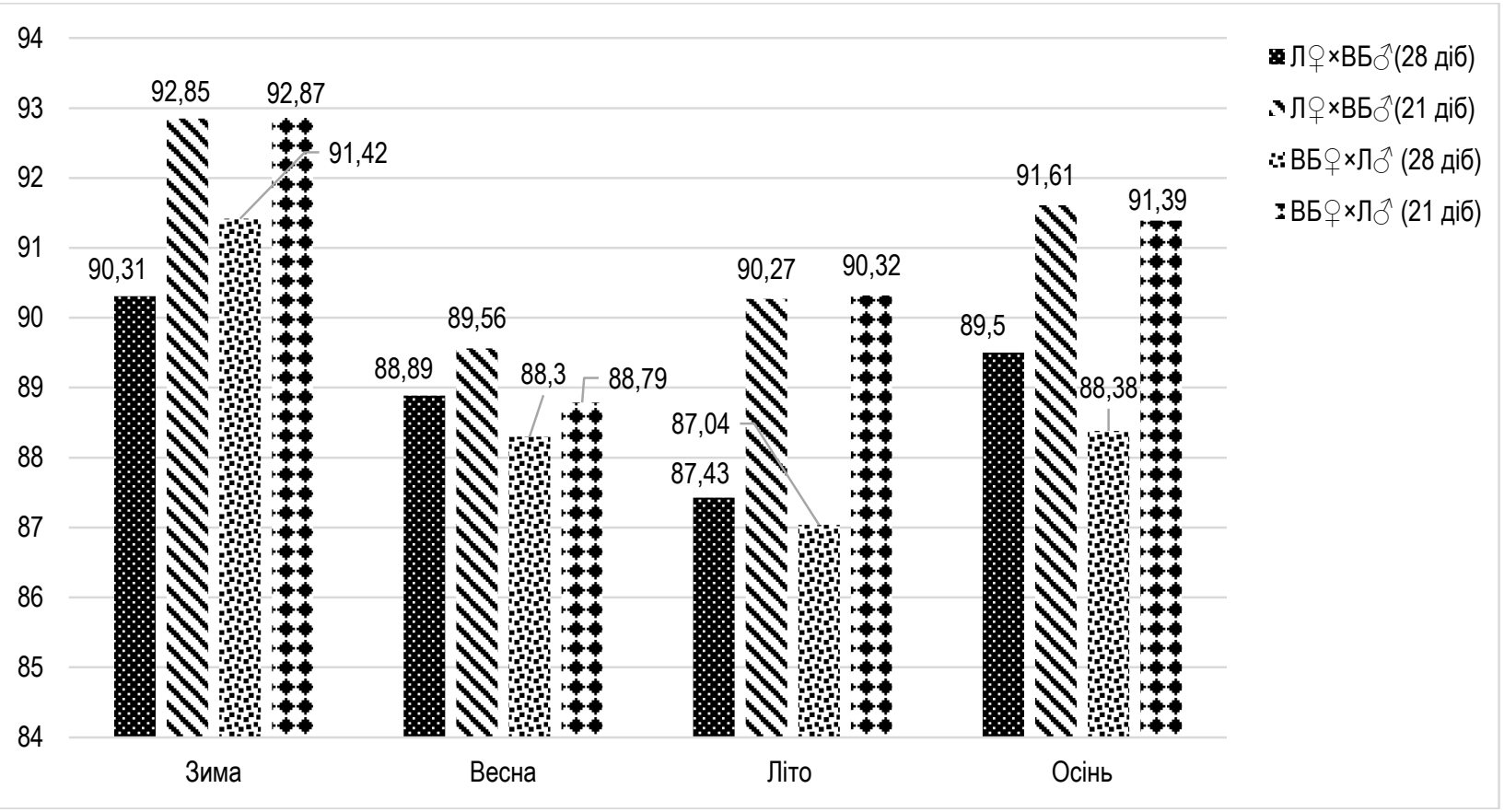

Рис. 3 Динаміка зміни показника збереженості поросят протягом року, \%

За показниками середньодобових приростів (рис. 4), спостерігалась тенденція до їх підвищення в осінньо - зимовий сезон року та деякого зниження у весняно-літній. Так у тварин із традиційною тривалістю підсисного періоду середньодобові прирости спадають протягом зимово - весняного періоду і починають відновлюватися в літньо - осінній. Цілком інша тенденція помічається у поросят при скороченому підсисному періоді, де відбувається збільшення приростів у зимово - весняну пору, та їх зниження літньо - осінню. У свиноматок породного поєднання Л $\bigcirc \times$ ВБ $\widehat{~ м і н л и в і с т ь ~ о з н а-~}$ ки коливалась від 221,1 г весною до 249,63 г восени. Тоді як, при скороченому терміні підсисного періоду не відбувалася його зміна влітку та восени $(211,77 \ldots 215,78$ г.), зимою в порівнянні з літом він зменшився на 21,06...14,73 г відповідно. Коливання середньодобового приросту за варіанту по-

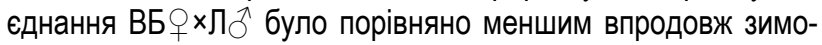
во-літнього періоду 223,55...230,11 г. При скороченому терміні відлучення приблизно рівні значення даного показника спостерігалися в літньо-осінній період 212,24...216,33 г., і спостерігалось його підвищення у весняний

Тобто середньодобові прирости поросят помірно залежали від пори року, за обох варіантів поєднання материнської породи та тривалість підсисного періоду. 


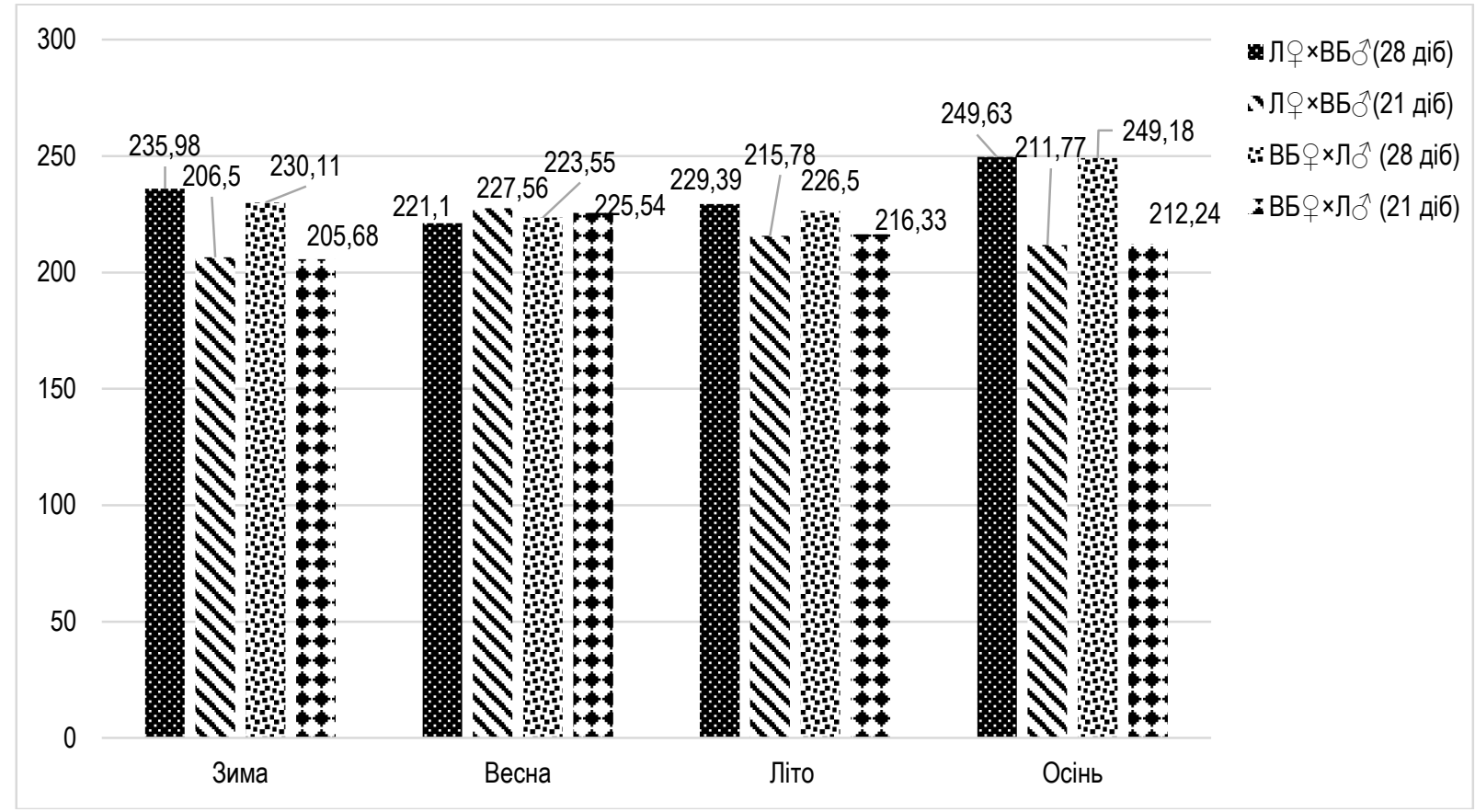

Рис. 4 Динаміка зміни показника середньодобового приросту поросят протягом року, г

За комплексною оцінкою відтворювальних якостей (рис. 5), також, спостерігаються зміни цього показнику протягом року. Так, у тварин з породнім поєднанням Л $>$ ×ВБ відбулися його коливання від 44,31 восени до 48,78 балів влітку. Сезонна динаміка комплексного індексу відтворювальних якостей залежала як від породних поєднань свиноматок так і термінів відлучення поросят. Так за традиційного тривалості підсисного періоду на початок року і його кінець спостерігаються майже ідентична кількість балів - 46,65 взимку та 46,72 восени. Тоді як, у свиноматок за скороченого терміну підсисного періоду суттєвих змін не було виявлено взимку, навесні та влітку - 46,18...47,39 балів. Восени даний показник становив 44,31 балів. У свиноматок поєднання ВБОхлð кількість балів була досить стабільною. Впродовж року коливання склали 45,62...47,39 бала. При тритижневій тривалості підсисного періоду кількість балів взимку та навесні була майже рівною - 47,39...47,74. У літньо - осінній період спостерігався спад за даним показником.

Таким чином, індекс комплексної оцінки відтворювальних якостей суттєво залежить від пори року за різної тривалості підсисного періоду та менше залежав від породних поєднань свиноматок.

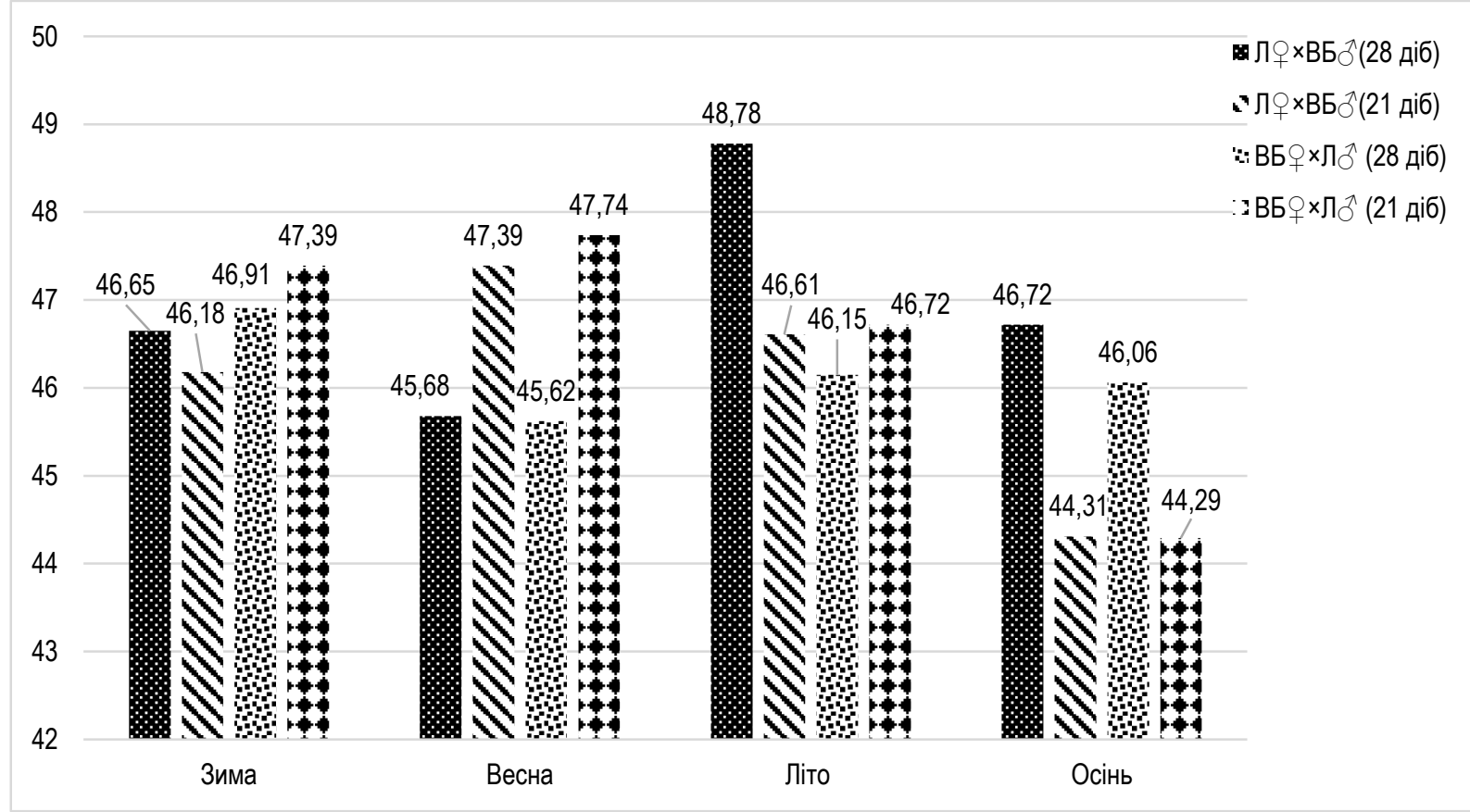

Рис. 5 Динаміка зміни показника комплексної оцінки відтворювальних якостей свиноматок протягом року, балів 


\section{Висновки.}

1.За обох поєднань свиноматки зі скороченим терміном підсисного періоду мали вищу великоплідність, кращу збереженість поросят і їх кількість на час відлучення, але меншу масу гнізда та однієї голови при відлученні взимку.

2.Навесні, свиноматки обох поєднань мали кращу потенційну та фактичну багатоплідність, великоплідність, більше народжували кнурців, мали більшу кількість поросят при відлученні за кращої їх збереженості, але мали нищу масу одного поросяти та гнізда поросят при відлученні.

3.Влітку, тварини з традиційною тривалістю підсисного періоду обох породних поєднань переважали за великоплідністю, масою гнізда на час народження, масою одного поросяти на час відлучення, масою гнізда поросят на час відлучення, середньодобовим, відносним та абсолютним приростами.

4.Восени, тварини зі скороченим терміном підсисного періоду переважали за масою гнізда при народженні, кількістю відлучених поросят та їх збереженістю, аналогів 3 традиційною тривалістю підсисного періоду, тоді як останні мали перевагу за великоплідностю, індивідуальною масою та масою гнізда на час відлучення, а також абсолютними середньодобовими та відносними приростами.

5.Відсутня суттєва різниця за кількістю балів комплексної оцінки відтворювальних якостей свиноматок протягом досліджуваного періоду.

\section{Список використаної літератури:}

1. Баньковська І. Б., Волощук В. М., Подобєд Л. І., Смислов, С. Ю. Модель оптимізації виробництва якісної свинини в сучасних умовах товарного свинарства. Науковий вісник Національного університету біоресурсів і природокористування України. Серія: Технологія виробництва і переробки продукції тваринництва. 2016. Вип. 250. С. 114-124.

2. Березовский Н.Д., Почерняев Ф.К., Коротков В.А. Методика моделирования индексов для использования их в селекции свиней. Методы улучшения процессов селекции, разведения и воспроизводства свиней (методические указания). М., 1986. С. 3-14.

3. Гераніна Л. А. Взаємозв'язок між багатоплідністю свиноматок і ростом поросят у різні сезони року. Свинарство. 2016. Вип. 68. С. 59-63.

4. Іванов В. О., Гук, М. С. Стресчутливість чистопородних та помісних свиней. Науково-технічний бюлетень /нституту тваринництва НААН. 2019. № 121. С. 121-127.

5. Козина Е. А., Жемер Ю. А. Рост и сохранность поросят при разных сроках отъема. Актуальные направления фундаментальных и прикладных исследований. 2019. С. 18-21.

6. Перевойко Ж, А., Косилов В. И. Воспроизводительная способность свиноматок крупной белой породы и её двухтрёхпородных помесей. Известия Оренбургского государственного аграрного университета. 2014. Вып. 6. С. 161 - 163.

7. Повод М. Г. Поведінка та продуктивність підсисних свиноматок впродовж року за різних умов утримання. Технологія виробництва і переробки продукції тваринництва. 2015 Вип. 2. С. 35 - 41.

8. Повод М. Г., Корж О. В., Нестеров А. М. Вплив пори року на відтворні якості свиноматок данської селекції. Вісник Сумського національного аграрного університету. Серія: Тваринництво. 2017. Вип. 5 (2). С. 111 - 113.

9. Польовий Л. В., Поліщук Т. В., А. П. Кульчицька. Формування м'ясної продуктивності та економічна ефективність виробництва свинини залежно від тривалості підсисного періоду. Аграрна наука та харчові технології. 2019. Вип. 4 (98). С. $180-188$.

10. Походня Г. С., Корниенко П. П., Малахова Т. А. Кренева Т. В., Маменко А. М. Эффективность выращивания поросят при различных сроках их отъёма. Проблеми зооінженерії та ветеринарної медицини. 2017. Вып. 33. Ч. 1. С. $129-134$.

11. Соколов Н. В., Зелкова Н. Г. Формирование маточного стада свиней для производства мясной свинины. Зоотехния. 2012. № 1. С. 22-23.

12. Стародубець О. О., Стародубець А. А. Вплив сезону року на відтворювальні якості свиноматок. Вісник аграрної науки Причорномор'я. 2015. Вип. 2 (84). Т. 2. С. 100 - 104.

13. Творогова Е. В. Экономические предпосылки внедрения технологии сверхраннего отъема поросят. Вестник Чувашского государственного педагогического университета им. И. Я Яковлева. 2013. № 2 (78). С. 159-162.

14. Lazarevich A.N., Efimova L.V., Ivanova O.V. Effectiveness analysis of crossbreding the hybrid sows with thoroughbred and terminal sires. In the World of Scientific Discoveries, Series B. 2017. № 2. P. 16-32.

15. Ushakova $S$. Influence of boars of different breeds on reproductive qualities of sows in multipedigree crossbreeding. Visnyk Agrarnoi Nauky. 2016. Issue. 94 (2). P. 68-69.

\section{References:}

1. Ban'kovs'ka, I. B., Voloshhuk, V. M., Podobjed, L. I., Smyslov, S. Ju. 2016. Model' optymizacii' vyrobnyctva jakisnoi' svynyny $v$ suchasnyh umovah tovarnogo svynarstva [Model of optimization of quality pork production in modern conditions of commercial pig breeding]. Naukovyj visnyk Nacional'nogo universytetu bioresursiv i pryrodokorystuvannja Ukrai'ny. Serija: Tehnologija vyrobnyctva i pererobky produkcii' tvarynnyctva, issue 250. pp. $114-214$.

2.Berezovskiy, N. D., Pochernyaev, F. K. and Korotkov, V. A. (1986). Metodika modelirovaniya indeksov dlya ispolzovaniya in $v$ selektsii sviney [Methodology for modeling indices for use in breeding pigs]. Metodyi uluchsheniya protsessov selektsii, razvedeniya i vosproizvodstva sviney (metodicheskie ukazaniya) [Methods for improving the processes of selection, breeding and reproduction of pigs (guidelines)]. pp. 3-14.

3.Geranina, L. A. 2016. Vzajemozvjjazok mizh bagatoplidnistju svynomatok i rostom porosjat u rizni sezony roku [Relationship between sow fertility and piglet growth in different seasons]. Svynarstvo, issue 68. S. pp. $59-63$. 
4.Ivanov, V. O., Guk, M. S. 2019. Streschutlyvist' chystoporodnyh ta pomisnyh svynej [Stress sensitivity of purebred and local pigs.]. Naukovo-tehnichnyj bjuleten' Instytutu tvarynnyctva NAAN, issue 121. pp. 121-127.

5.Kozina, E. A., Zhemer, Ju. A. 2019. Rost i sohrannost' porosjat pri raznyh srokah otema [Growth and safety of piglets at different weaning dates.]. Aktual'nye napravlenija fundamental'nyh i prikladnyh issledovanij. pp. 18-21.

6.Perevojko, Zh, A., Kosilov, V. I. 2014. Vosproizvoditel'naja sposobnost' svinomatok krupnoj beloj porody i ejo dvuhtrjohporodnyh pomesej [Reproductive ability of sows of large white breed and its two-three-breed crosses]. Izvestija Orenburgskogo gosudarstvennogo agrarnogo universiteta, issue 6. pp. 161 - 163.

7.Povod, M. G. 2015. Povedinka ta produktyvnist' pidsysnyh svynomatok vprodovzh roku za riznyh umov utrymannja [Behavior and productivity of suckling sows during the year under different housing conditions]. Tehnologija vyrobnyctva i pererobky produkcii' tvarynnyctva, issue 2. pp. $35-41$.

8.Povod, M. G., Korzh, O. V., Nesterov, A. M. 2017. Vplyv pory roku na vidtvorni jakosti svynomatok dans'koi' selekcii' [Influence of the season on the reproductive qualities of sows of Danish selection]. Visnyk Sums'kogo nacional'nogo agrarnogo universytetu. Serija: Tvarynnyctvo, issue 5(2). pp. $111-113$.

9.Pol'ovyj, L. V., Polishhuk T. V., Kul'chyc'ka, A. P. 2019. Formuvannja m'jasnoi' produktyvnosti ta ekonomichna efektyvnist' vyrobnyctva svynyny zalezhno vid tryvalosti pidsysnogo periodu [Formation of meat productivity and economic efficiency of pork production depending on the duration of the suckling period]. Agrarna nauka ta harchovi tehnologii', issue 4 (98). pp.180 - 188.

10. Pohodnja, G. S., Kornienko, P. P., Malahova, T. A. Kreneva, T. V., Mamenko, A. M. 2017. Jeffektivnost' vyrashhivanija porosjat pri razlichnyh srokah in otjoma [Efficiency of cultivation of piglets at various terms of their weaning]. Problemi zooinzhenerii ta veterinarnoï medicini, vol. 33. issue 1. pp. 129-134.

11. Sokolov, N. V., Zelkova, N. G. 2012. Formirovanie matochnogo stada svinej dlja proizvodstva mjasnoj svininy [Formation of brood pigs for the production of meat pork]. Zootehnija, no. 1. pp. 22-23.

12. Starodubec', O. O., Starodubec', A. A. 2015. Vpliv sezonu roku na vidtvorjuval'ni jakosti svinomatok [Influence of the season of the year on the reproductive qualities of sows]. Visnik agrarnoï nauki Prichornomor'ja. issue 2 (84). pp. $100-104$.

13. Tvorogova, E. V. 2013. Jekonomicheskie predposylki vnedrenija tehnologii sverhrannego ot\#ema porosjat [Economic prerequisites for the introduction of technology for superearly weaning of piglets]. Vestnik Chuvashskogo gosudarstvennogo pedagogicheskogo universiteta im. I. Ja Jakovleva, no. 2 (78). pp. 159-162.

14. Lazarevich, A.N., Efimova, L.V., Ivanova, O.V. 2017. Effectiveness analysis of crossbreding the hybrid sows with thoroughbred and terminal sires. In the World of Scientific Discoveries, Series B, no. 2. pp. 16-32.

15. Ushakova, S. 2016. Influence of boars of different breeds on reproductive qualities of sows in multipedigree crossbreeding. Visnyk Agrarnoi Nauky, issue 94(2). pp. 68-69.

Shvachka Ruslan Petrovich, Postgraduate student

Povod Mykola Hryhorovych, Doctor of Agricultural Sciences, Professor

Sumy National Agrarian University (Sumy, Ukraine)

Andriychuk Valery Fedorovich, PhD of Agricultural Sciences, Docent

Polissya National University (Zhytomyr, Ukraine)

Dependence of reproductive qualities of sows on the duration of the sucking period, the option of combination of breeds at different seasons

The dependence of reproductive qualities of F1 sows of Irish origin in direct and reciprocal crossing of Great White and Landrace breeds on the duration of the lactation period during the four seasons in the Steppe of Ukraine was studied. It was found that in the winter season there were no differences between groups of pigs of different combinations and weaning dates for the total number of piglets, fertility, sex of piglets and the weight of their nest at birth. At the same time, with both combinations, sows with a reduced suckling period had a higher fertility by $0,02 \mathrm{~kg}(p<0,01)$, better by $1,45 \% \ldots 2,54 \%(p<0,01)$ survival of piglets and as a consequence greater by $0,17 \ldots 0,29$ heads their number at weaning, but lower growth intensity - and as a consequence less by $25,58 \ldots 27,48 \mathrm{~kg}$ nest weight and 2,11 .. 2,26 kg weight of one head at weaning, In the spring, sows of both combinations had better by $0.28 \ldots .0 .56$ heads potential and by $0.47 \ldots 0.69$ heads actual fertility, by $0,04-0,05 \mathrm{~kg}$ high fertility, more gave birth to boars, had more by $0,51 \ldots 0,68$ head $(p<0,001)$ number of piglets at weaning at the best on their safety, but had a lower 1,65...1,69 $\mathrm{kg}(p$ $<0,001$ ) weight of one piglet and 17,25..20,72 kg weight of the nest of piglets at weaning. According to the intensity of growth of piglets before weaning, there was a tendency to increase it in the nests of queens with a shortened suckling period. In the summer, no significant differences were found between the sows of the experimental groups in terms of the total number of piglets at birth and fertility. However, animals with the traditional duration of the suckling period of both breed combinations prevailed in high fertility by $0,04-0,05 \mathrm{~kg}(p<0,001)$, nest weight at birth by $0,37 \ldots 0,47 \mathrm{~kg}$, weight of one piglet per weaning time, and by $1,83 \ldots 1,93$, the weight of the nest of piglets at this time 19,18...19,72 $\mathrm{kg}$, the average daily, relative and absolute increments - there was a worse 2,84 and 3,28\% preservation and 0,47 ...0,59 number of piglets at the time of weaning. In autumn, animals with a shortened suckling period predominated by nest weight of piglets at birth by 1,81 and $2,21 \mathrm{~kg}(p<0,001)$, their safety by $2,11 \ldots 3,01 \%(p<0,01)$ of their counterparts with the traditional duration of the suckling period, while the latter had an advantage of $0,08 \mathrm{~kg}$ in high fertility, $0,26 \ldots$ 0,39 heads in the number of piglets at weaning, $2,57 \ldots 2,58 \mathrm{~kg}(p<0,01)$ by individual weight, and by $29,38 . . .32,95 \mathrm{~kg}$ of nest weight at the time of weaning $(p<0,001)$, as well as $2,49 \ldots 2,50 \mathrm{~kg}(p<0,001)$ in absolute terms, by $36,94 \ldots 37,86 \mathrm{~g}$ on average daily $(p$ $<0,01)$ and by $18,21 \ldots 18,51 \%$ in relative increments. Analyzing the changes in reproductive quality of sows of both genotypes, it was found that their fertility depended more on the season with a reduced weaning period than in the traditional, while the number of piglets at weaning had significant seasonal fluctuations in both traditional and reduced suckling duration in pigs. The season had a 
significant effect on the survival of piglets in all experimental groups of animals, regardless of genotype or duration of the suckling period. At the same time, the average daily gain of piglets was moderately dependent on the season, with both combinations of the mother breed and the length of the suckling period. The index of comprehensive assessment of reproductive qualities of sows significantly depended on the season for different lengths of the suckling period and was less dependent on breed combinations of sows. tensity.

Key words: sow, piglets, suckling period, weaning period of piglets, fertility, safety, breed combination, season, growth in-

Дата надходження до редакції: 28.10.2020 р. 